\title{
QUALITY EVALUATION OF CHINCHIN PRODUCED FROM COMPOSITE FLOURS OF WHEAT AND GERMINATED FINGER MILLET FLOUR
}

\author{
*Abioye, V.F., Olodude, O.A., Atiba, V and Oyewo, I.O. \\ Department of Food Science, Ladoke Akintola University of Technology, \\ Ogbomoso, Nigeria \\ *Corresponding Author: vfabioye@lautech.edu.ng
}

\begin{abstract}
Composite flour was produced from germinated finger millet and wheat and its potentials in producing nutritious chinchin, a traditional Nigerian snack was investigated. Finger millet was sorted, germinated, dried and milled into flour. Simplex Lattice Designs was used in generating different formulations (100:0, $88: 12,75: 25$ and 50:50) of wheat and germinated finger millet, respectively, and used to produce chinchin. The composite flour was analyzed for proximate, minerals, antinutritional and functional properties while the chinchin samples were subjected to sensory evaluation. The values obtained for moisture, protein, fat, crude fibre, ash and carbohydrate were in the ranges of 10.47 to $10.71 \%$, 8.74 to $9.64 \%, 1.79$ to $1.95 \%, 1.38$ to $1.55 \%, 2.31$ to $2.57,73.58$ to $75.31 \%$, respectively. The loose and packed bulk density ranged from 0.61 to $0.62 \mathrm{~g} / \mathrm{cm}^{3}$ and 0.005 to $0.013 \mathrm{~g} / \mathrm{cm}^{3}$. The calcium, iron, magnesium, potassium and phosphorus content of flour ranged from 0.1150 to $0.1300 \mathrm{mg} / \mathrm{l}, 12.033$ to 13.633 $\mathrm{mg} / \mathrm{l}, 0.158$ to $0.187 \mathrm{mg} / \mathrm{l}, 0.389$ to $0.428 \mathrm{mg} / \mathrm{l}$ and 0.271 to $0.296 \mathrm{mg} / \mathrm{l}$, respectively. The anti-nutritional properties reduced with processing. This study has shown the potentials of composite flour from wheat and germinated finger millet in production of nutritious chinchin.
\end{abstract}

Keyword: Finger millet, wheat flour, chinchin, snacks, composite flour 


\section{INTRODUCTION}

Chinchin is a traditional Nigerian snack prepared using wheat flour, butter, milk and eggs from which a stiff paste is made. It is deep-fried until golden brown and crispy. It is quite popular across Nigeria and in most of Western Africa countries. Chinchin is sweet to taste, slightly hard and can be compared to a harder version of a doughnut and sometimes prepared by baking instead of frying (Adegunwa et al., 2014). Wheat (Triticum spp) has been the major cereal grain used in the bakery industry due to its gluten proteins to form viscoelastic dough required to bake leavened bread. These gluten proteins are necessary for the production of the great variety of foods associated with wheat around the world.

Finger millet is one of the staple cereals grown in the semi-arid subtropical and tropical regions of Africa and Asia and it adapts to various agro-climatic conditions. It is one of the most nutritious cereal grains which tastes better than most other cereal grains. Finger millet is a very good source of dietary fibre, micronutrients and polyphenols. It is also rich in proteins, iron, calcium, phosphorus, fibre, and vitamin content. It serves as a good diet for growing children, women, aged people, and individuals with malnutrition, diabetes and obesity problems but underutilized due to grain size and anti-nutritional value (Chappalwar et al., 2013; Manjula and Visvanathan, 2014; Ramashia et al., 2019). Due to recent urbanization and civilization, there is an increase in demand for bakery products and hence more demand for importation of wheat which has a negative effect on Nigeria's economy. Food processors are also faced with the challenge of producing food products containing functional ingredients to meet the nutritional and health requirement of individuals.

Finger millet is high in dietary fibre, minerals (calcium, magnesium and phosphorus), essential amino acids and phytochemicals. (Devi et al., 2014; Owheruo, et al., 2019; Ramashia et al., 2019). This contributes to the reduction of chronic diseases such as lowering of high blood pressure, ischemic strokes, cardiovascular diseases, cancers, obesity. But it is underutilized due to the presence of anti-nutrient which can be removed by processing such as germination (Abioye et al., 2018). However, it has been observed that despite its nutritional advantages, excellent storage properties and health beneficial properties, there is little research and transformation on finger millet as compared to other cereal grains such as maize, sorghum, rice and wheat (Ramashia et al., 2019). Therefore, this research investigated the effect of germinated finger millet substitution on quality attributes of wheat flour and its potentials in producing a nutritious and functional snack. 


\section{MATERIALS AND METHODS \\ Materials}

Finger millet was obtained from a local farm market in Jos, Plateau state, Nigeria while other materials were bought from a local market in Ogbomoso, Oyo, State. All chemicals used were ensured to be of analytical grade.

\section{Methods}

\section{Production of Germinated Finger Millet}

One hundred grams $(100 \mathrm{~g})$ of finger millet grain were weighed and sorted to remove extraneous materials. The surface of the millet seeds was sterilized for $30 \mathrm{~min}$ in a $1 \%$ sodium hypochlorite solution. These seeds were rinsed five times with distilled water $(1: 3 \mathrm{w} / \mathrm{v})$ and soaked in a glass beaker for nine hours in tap water $(1: 3 \mathrm{w} / \mathrm{v})$. The presoaked seeds were then allowed to sprout on sterile germinating trays lined with filter paper and kept moist by layers of damp cotton wool. The seeds were germinated at room temperature $\left(28 \pm 2{ }^{\circ} \mathrm{C}\right)$. After germination, samples were collected after $72 \mathrm{~h}$ and dried using cabinet dryer (45 ${ }^{\circ} \mathrm{C}$ for $12 \mathrm{~h}$ ). The germinated seeds were ground, sieved $(300 \mu \mathrm{m})$ and packaged in polyethylene bags until further analyzes.

\section{Preparation of wheat- finger millet composite flour}

Simplex Lattice Designs was used to generate different formulations of wheat and germinated finger millet, respectively: (100:0, 88:12, 75:25 and 50:50).

\section{Preparation of Chinchin}

Chinchin was prepared using the method outlined by Akubor (2004) with slight modifications. Hundred grams (100 g) of the composite flour was weighed and sieved (250-micron particle size). All other ingredients (sugar, salt and baking powder) were also added. Margarine, eggs and milk were turned in and mixed to form dough. The dough was kneaded, rolled out $(2 \mathrm{~cm}$ thick) and cut into small squares $(2 \mathrm{~cm}$ by $2 \mathrm{~cm})$. It was deep fried $\left(180{ }^{\circ} \mathrm{C}, 8 \mathrm{~min}\right)$ till it turned golden brown, drained, cooled, packaged and stored at room temperature $\left(28 \pm 2{ }^{\circ} \mathrm{C}\right)$.

\section{Analyses}

\section{Determination of the Chemical Composition of the Flour Blends.}

The flour samples were analyzed for moisture, ash, crude fibre, protein $\left(\mathrm{N}^{*} 6.25\right)$, crude fat and the carbohydrate determined by difference (Association of Official Analytical Chemists, 2010). Selected minerals (calcium, phosphorus, potassium, magnesium, and sodium) were determined by atomic absorption 
spectrophotometer (AOAC, 2010). The tannin content of the flour mixes was determined using the method described by Makkar et al. (1993). Phytate content was determined using spectrophotometric method as described by Pearson (1976) while saponin content was determined using titration method.

\section{Functional Properties}

The bulk density of the flour samples was determined using the method described by Narayana and Narasinga-Rao (2006). Water and oil absorption capacity of the flour was determined as described by Oyeyinka et al. (2013). The foam capacity (FC) and foam stability (FS) of the flour samples were determined as described by Onwuka (2005).

\section{Sensory Evaluation of Chinchin Samples}

Sensory evaluation was carried out by a team comprising of 40 panelists in the sensory laboratory. Each panelist was served with chinchin made from the flour mixes. Panelists were asked to evaluate the colour, taste, texture, crispiness, appearance and overall acceptance of the chinchin using the 9-point hedonic scale with 1 dislike extremely and 9 like extremely.

\section{Statistical Analysis}

All data obtained were subjected to Analysis of Variance (ANOVA) and the means separated using Duncan's multiple range test to detect significant difference $(p<0.05)$ among the samples.

\section{RESULTS AND DISCUSSION \\ Results of the Chemical Composition of the Flour}

The proximate composition of the flour is shown in Table 1. The moisture content of the flour ranged from 10.47 to $10.71 \%$. The value falls below the $14 \%$ standard recommended for shelf stable storage of flour products (Ukpabi and Ndimele, 1990; Adeleke and Odedeji, 2010). The protein content of the flour samples ranged from 8.74 to $9.64 \%$ with the lowest protein content recorded in $100 \%$ wheat flour while increase was recorded in the protein content of the flour samples with increase in germinated flour substitution. The increases in crude protein could be due to enzyme hydrolysis of the insoluble protein to soluble protein, which increased the protein availability. It could also be attributed to the fact that some amino acids are produced in excess amount of the requirement during protein synthesis and these tend to accumulate in free amino acid pool (Echendu et al., 2009). Other researchers have also attributed the increase to the 
degradation of storage protein and synthesis of new protein and other materials (Khademi, 1990; Ali and Elozeiri, 2017).

The fat content of the flour ranged from 1.79 to $1.95 \%$ with $100 \%$ wheat flour having the lowest fat content. The result showed that fat content increased following the inclusion of germinated finger millet flour. This result is in line with the previous report that Germination caused fat content to increase significantly in pearl millet (Maneemegalai and Nandakumar, 2011)

The crude fibre of the flour samples ranged from 1.38 to $1.55 \%$ with combination obtained at $100 \%$ wheat flour having the lowest crude fibre content. The result showed that there was increase in the crude fibre with the inclusion of germinated finger millet flour. This increase in crude fibre might be due to starch breakdown during germination. Similar report was recorded by Nkhata et al. (2018). Thus, it may be inferred that the increased contents of protein, mineral matter and fibre in the sprouts were only apparent and mainly attributable to the disappearance of starch during germination. Though crude fibre does not contribute nutrients to the body, it adds bulk to food thus facilitating bowel movements (peristalsis) and preventing many gastrointestinal diseases in man (Grundy et al., 2016). The content ranged from 2.31 to $2.57 \%$ with combination obtained at $100 \%$ wheat flour having the lowest ash content. The result showed that there was increase in the ash content with the inclusion of germinated finger millet flour. The increase in ash content is an indication of increase in mineral content of the food formulations. This is a welcome development, as consumers will have the opportunity of a balance in their diet due to the increased levels of minerals from the ash (Balogun et al., 2012). The carbohydrate content ranged from 71.82 to $73.10 \%$ with combination obtained at $100 \%$ wheat flour having the lowest carbohydrate content.

The mineral content of flour ranged from 0.1150 to $0.1300(\mathrm{mg} / \mathrm{l}), 12.033$ to 13.633 (mg/l), 0.158 to $0.187(\mathrm{mg} / \mathrm{l}), 0.389$ to $0.428(\mathrm{mg} / \mathrm{l})$ and 0.271 to 0.296 $(\mathrm{mg} / \mathrm{l})$ for calcium, iron, magnesium, potassium and phosphorus, respectively. Higher values were recorded with germinated finger millet substitution. This could be attributed to the high contents of these minerals in germinated finger millet. Finger millet has been reported to be a good source of minerals (Singh and Raghuvansh, 2012; Dinesh et al., 2014). The anti-nutritional properties of the flour reduced with germination process. Similar results were observed and reported that germination is an effective method in reducing antinutritional factors (Abioye et al., 2018; Ekta and Sarita, 2018). 
Table 1: Functional properties of the flour mixes

\begin{tabular}{llllll}
\hline Sample & $\begin{array}{l}\text { Loose } \\
\text { bulk } \\
\text { Density } \\
\left(\mathrm{g} / \mathrm{cm}^{3}\right)\end{array}$ & $\begin{array}{l}\text { Parked bulk } \\
\text { Density } \\
\left(\mathrm{g} / \mathrm{cm}^{3}\right)\end{array}$ & $\begin{array}{l}\text { Water } \\
\text { Capacity } \\
(\%)\end{array}$ & $\begin{array}{l}\text { Oil } \\
\text { Absorption } \\
\text { Capacity } \\
(\%)\end{array}$ & $\begin{array}{l}\text { Swelling } \\
\text { capacity } \\
(\%)\end{array}$ \\
\hline A & $0.61^{\mathrm{a}}$ & $0.005^{\mathrm{a}}$ & $123.33^{\mathrm{a}}$ & $105.67^{\mathrm{a}}$ & $15.81^{\mathrm{b}}$ \\
B & $0.61^{\mathrm{a}}$ & $0.008^{\mathrm{ab}}$ & $126.00^{\mathrm{b}}$ & $110.33^{\mathrm{b}}$ & $15.91^{\mathrm{a}}$ \\
C & $0.61^{\mathrm{a}}$ & $0.011^{\mathrm{bc}}$ & $128.00^{\mathrm{b}}$ & $114.67^{\mathrm{c}}$ & $16.07^{\mathrm{d}}$ \\
D & $0.62^{\mathrm{a}}$ & $0.013^{\mathrm{c}}$ & $130.67^{\mathrm{c}}$ & $119.67^{\mathrm{d}}$ & $16.09^{\mathrm{c}}$ \\
\hline
\end{tabular}

Means with the same superscript along the same column are not significantly different $(p>0.05)$

Sample $A=100 \%$ wheat flour

Sample $B=88 \%$ Wheat flour and $12 \%$ Germinated finger millet

Sample $\mathrm{C}=75 \%$ wheat flour and $25 \%$ Germinated finger millet

Sample $D=50 \%$ wheat flour and $50 \%$ Germinated finger millet

\section{Functional Properties of the Flour}

The functional properties of the flour are shown in Table 2. The values obtained for bulk density of the flour ranged from 0.61 to 0.62 and 0.005 to $0.013 \mathrm{~g} / \mathrm{cm}^{3}$, respectively, for loose and packed bulk density. Generally, the bulk density of food materials is affected by the particle size and the density of the food. It is therefore an important factor in food packaging (Menon et al., 2015). The Water Absorption Capacity (WAC) and Oil Absorption Capacity (OAC) ranged from 123.33 to $130.67 \%$ and 105.67 to $119.67 \%$, respectively. The water absorption capacity (WAC) of the composite flour significantly increased as the level of germinated finger millet flour substitution increased. WAC is important in foods where water will be absorbed without dissolution of protein, thus increasing their viscosity and body thickening (Akinwale et al., 2017). Thus, this implies that the addition of finger millet improves the reconstitution ability. OAC increased as germinated finger millet substitution increased. OAC tends to cause an increase in the functionality of these composite flours in retaining flavour and improvement on the mouth feel. Also, the swelling capacity of the samples ranged from 15.81 to $16.09 \%$ with higher values recorded in substituted flour samples. The difference in swelling may be attributed to the variation in the amylose content and other minor components of the flour (Oyeyinka et al., 2019). Swelling capacity is a function of process conditions, nature of material and type of treatment. The high swelling capacity could be an advantage in production of bakery products. 
Table 2: Chemical composition of the flour mixes

\begin{tabular}{lccllllllll}
\hline Sample & $\begin{array}{c}\text { Moisture } \\
\text { Contents } \\
(\%)\end{array}$ & $\begin{array}{c}\text { Protein } \\
\text { contents } \\
(\%)\end{array}$ & $\begin{array}{l}\text { Fat } \\
\text { contents } \\
(\%)\end{array}$ & $\begin{array}{l}\text { Crude } \\
\text { Fibre } \\
(\%)\end{array}$ & $\begin{array}{l}\text { Ash } \\
(\%)\end{array}$ & $\begin{array}{l}\text { Carbohy } \\
\text { drates } \\
(\%)\end{array}$ & $\begin{array}{l}\text { Phytate } \\
(\mathrm{mg} / 100 \\
\mathrm{g})\end{array}$ & $\begin{array}{l}\text { Oxalate } \\
(\mathrm{mg} / 100\end{array}$ & $\begin{array}{l}\text { Tannin } \\
(\mathrm{mg} / 10\end{array}$ & $\begin{array}{l}\text { Trypsin } \\
\text { inhibitor } \\
(\mathrm{mg} / 100\end{array}$ \\
\hline A & $10.47^{\mathrm{a}}$ & $8.74^{\mathrm{a}}$ & $1.79^{\mathrm{a}}$ & $1.38^{\mathrm{a}}$ & $2.31^{\mathrm{a}}$ & $75.31^{\mathrm{d}}$ & $0.1663^{\mathrm{a}}$ & $0.117^{\mathrm{a}}$ & $0.002^{\mathrm{a}}$ & $2.58^{\mathrm{a}}$ \\
B & $10.57^{\mathrm{b}}$ & $8.93^{\mathrm{b}}$ & $1.83^{\mathrm{a}}$ & $1.43^{\mathrm{b}}$ & $2.36^{\mathrm{a}}$ & $74.88^{\mathrm{c}}$ & $0.1803^{\mathrm{b}}$ & $0.128^{\mathrm{b}}$ & $0.002^{\mathrm{b}}$ & $2.81^{\mathrm{b}}$ \\
C & $10.63^{\mathrm{bc}}$ & $9.43^{\mathrm{c}}$ & $1.89^{\mathrm{b}}$ & $1.49 \mathrm{c}$ & $2.51^{\mathrm{b}}$ & $74,05^{\mathrm{b}}$ & $0.1867^{\mathrm{c}}$ & $0.137^{\mathrm{c}}$ & $0.002^{\mathrm{c}}$ & $2.90^{\mathrm{c}}$ \\
D & $10.71^{\mathrm{c}}$ & $9.64^{\mathrm{d}}$ & $1.95^{\mathrm{c}}$ & $1.55^{\mathrm{d}}$ & $2.57^{\mathrm{b}}$ & $73.58^{\mathrm{a}}$ & $0.1957^{\mathrm{d}}$ & $0.144^{\mathrm{d}}$ & $0.002^{\mathrm{d}}$ & $3.00^{\mathrm{d}}$ \\
\hline
\end{tabular}

Means with the same superscript along the same column are not significantly different $(p>0.05)$

\section{Sensory Evaluation of Chinchin}

The result of the sensory evaluation of the chinchin samples is as shown in Table 3. The sensory evaluation revealed that chinchin made from $100 \%$ wheat flour had better acceptability. This could be due to the fact that people are more familiar with it than chinchin from other composite samples. Otunola et al (2013) similarly reported that control cookies had higher acceptability than Moringa enriched samples, which could be due to the same reason of familiarity with the control. The chinchin produced from composite flour with $12 \%$ finger millet flour was rated closely in almost all the quality attributes evaluated. This result suggests that there are potentials for germinated finger millet flour in the snack industry.

Table 3: Sensory Evaluation of Chinchin

\begin{tabular}{llllllll}
\hline & Colour & Flavour & Taste & Crispness & Appearance & Texture & $\begin{array}{l}\text { Overall } \\
\text { acceptability }\end{array}$ \\
\hline A & $7.55^{\mathrm{c}}$ & $7.00^{\mathrm{b}}$ & $7.50^{\mathrm{a}}$ & $7.15^{\mathrm{b}}$ & $7.35^{\mathrm{b}}$ & $7.00^{\mathrm{b}}$ & $7.60^{\mathrm{b}}$ \\
$\mathrm{B}$ & $6.15^{\mathrm{a}}$ & $5.95^{\mathrm{a}}$ & $5.55^{\mathrm{b}}$ & $5.35^{\mathrm{a}}$ & $5.80^{\mathrm{a}}$ & $5.55^{\mathrm{a}}$ & $5.75^{\mathrm{a}}$ \\
$\mathrm{C}$ & $6.50^{\mathrm{ab}}$ & $5.55^{\mathrm{a}}$ & $5.70^{\mathrm{b}}$ & $5.90^{\mathrm{a}}$ & $6.05^{\mathrm{a}}$ & $6.00^{\mathrm{a}}$ & $5.60^{\mathrm{a}}$ \\
$\mathrm{D}$ & $6.20^{\mathrm{bc}}$ & $5.05^{\mathrm{b}}$ & $5.35^{\mathrm{a}}$ & $5.10^{\mathrm{b}}$ & $5.70^{\mathrm{ab}}$ & $5.25^{\mathrm{b}}$ & $5.45^{\mathrm{b}}$ \\
\hline
\end{tabular}

Means with the same superscript along the same column are not significantly different $(p>0.05)$

Sample $A=100 \%$ wheat flour

Sample $B=88 \%$ Wheat flour $+12 \%$ Germinated finger millet

Sample $C=75 \%$ wheat flour $+25 \%$ Germinated finger millet

Sample $D=50 \%$ wheat flour $+50 \%$ Germinated finger millet 


\section{CONCLUSION AND RECOMMENDATION}

The study has shown that germination is an effective method in reducing antinutrients in finger millet and substitution of germinated finger millet into wheat flour had effects on the chemical composition and functional properties of the flour. This implies that the use of germinated finger millet flour in chinchin production has the potentials to improve the nutritional value of the food product and thus, enhance the economic value of the crop.

\section{REFERENCES}

Abioye, V.F., Ogunlakin, G.O, and Taiwo, G. (2018). Effect of Germination on Anti-oxidant Activity, Total Phenols, Flavonoids and Anti-nutritional Content of Finger Millet Flour. Journal of Food Process Technology, 9, 1-4.

Adegunwa, M.O., Ganiyu, A.A., Bakare, H.A. and Adebowale, A.A. (2014). Quality evaluation of composite millet-wheat Chinchin. Agriculture and Biology Journal of North America, 5(1), 33-39.

Adeleke, R.O. and Odedeji, J.O. (2010). Functional properties of wheat and sweet potato flour blend. Pakistan Journal of Nutrition, 96, 535-538.

Akinwale, T.E., Shittu, T.A, Adebowale A.A., Adewuyi, S., and Abass, A.B. (2017). Effect of soy protein isolate on the functional, pasting, and sensory acceptability of cassava starch-based custard. Food Science Nutrition, 5(6), 1163-1169.

Akubor, P.I. (2004). Protein contents, physical and sensory properties of Nigerian snack foods (cake, chin-chin and puff-puff) prepared from cowpea-wheat flour blends. International Journal of Food Science and Technology, 39 (4), 419-424.

Ali, A.S., and Elozeiri, A.A. (2017). Metabolic processes during seed germination In: J.C. Jimenez-Lopez (Ed.) Advances in Seed Biology.

Association of Official Analytical Chemists (2010). Official Methods of Analysis, (17th ed.) Association of Official Analytical Chemists", Washington, D.C., U.S.A.

Balogun, M.A., Karim, O.R., Kolawole, F.L. and Solarin, A.O. (2012). Quality attributes of tapioca meal fortified with fortified with defatted soyflour. Agrosearch, 12(1), 61-67.

Chappalwar, V.M., Peter, D., Bobde, H. and John, S.M. (2013). Quality characteristics of cookies prepared from oats and finger millet based composite flour. Engineering Science and Technology: An International Journal (Toronto, Ont.), 3(4), 667-683. 
Devi, P.B., Vijayabharathi, R., Sathyabama, S., Malleshi, N. G. and Priyadarisini, V.B. (2014). Health benefits of finger millet (Eleusine coracana L) polyphenols and dietary fibre - Review. Journal of Food Science and Technology, 6(6), 1021-1040.

Dinesh, A., Rohit, K and Chaurasia, S (2014). Finger millet for nutritional security and Source of food. Advance Journal of Food Science and Technology, 2(4), 184-190.

Echendu, C.A., Obizoba, I.C and Anyika, J.U (2009). Effects of germination on chemical composition of groundbean (Kerstingiella geocarpa harm) Seeds. Pakistan Journal of Nutrition, 8, 1849-1854.

Ekta, S.C and Sarita (2018). Effects of processing (germination and popping) on the nutritional and anti-nutritional properties of finger millet (Eleusine Coracana). Current Research in Nutrition and Food Science, 6(2), 566572.

Grundy, M.M., Edwards, C.H., Mackie, A.R., Gidley, M.J., Butterworth, P.J and Ellis, P.R (2016). Re-evaluation of the mechanisms of dietary fibre and implications for macronutrient bio-accessibility, digestion and postprandial metabolism. British Journal of Nutrition, 116, 816-833.

Khademi, M. (1990). Storage protein degradation and proteolytic enzyme activities during germination of water stressed impatiens seeds. Retrospective Theses and Dissertations. Available online at https://lib.dr.iastate.edu/rtd/9378.

Makkar, H.P.S., Blummed, M.B., and Becken, N.K. (1993). Determination of tannins and their correlation with chemical and protein precipitation method. Journal of Food Science and Agriculture, 61, 161-185.

Manjula, B. and Visvanathan, R. (2014). Process optimization of extruded breakfast cereal from rice mill brokens-finger millet-maize flour blends. International Journal of Food and Nutritional Sciences, 3(4), 6671.

Maneemegalai, S. and Nandakumar, S. (2011). Biochemical studies on the germinated seed of Vigna radiata (L.) R. Wilczek, Vigna mungo (L.) Hepper and Pennisetum typhoides (Burm f.) Stapf and E. Hub. International Journal of Agricultural Research, 6, 601-606

Menon, L., Majumdar, S.D. and Ravi, U. (2015). Development and analysis of composite flour bread. Journal of Food Science and Technology, 52(7), 4156-4165. 
Narayana, K., and Narasinga-Rao, M.S. (2006). Effect of Partial Proteolysis on the Functional Properties of Winged bean (Psophocarpus tetragonolobus) Flour. Journal of Food Science, 49(3), 944 - 947.

Nkhata., S.G., Ayua, E., Kamau E.H. and Shingiro, J. (2018). Fermentation and germination improve nutritional value of cereals and legumes through activation of endogenous enzymes. Food Science and Nutrition, 6(2), $2446-2458$.

Onwuka G.I. (2005). Food Analysis and Instrumentation: Theory and Practice. Napthali Prints a Division of HG Support Nigerian Ltd, Lagos.

Otunola, G.A., Arise, A.K.., Sola-Ojo, F.E., Nmom, I.O., and Toye, A.A. (2013). The effects of addition of Moringa leaf waste fibre on proximate and sensory characteristics of cookies. Agrosearch, 13(1), 69-75.

Owheruo, J.O., Ifesan, B.O.T. and Kolawole, A.O. (2019). Physicochemical properties of malted finger millet (Eleusine coracana) and pearl millet (Pennisetum glaucum). Food Science and Nutrition, 7, 476-482.

Oyeyinka, S.A., Oyeyinka, A.T., Karim, O.R., Kayode, R.M.O., Balogun, M.A., and Balogun O.A. (2013). Quality attributes of Weevils (Callosobruchus Maculatus) infested cowpea (Vigna Unguiculata) products. Nigeria Journal of Agriculture, Food and Environment, 9(3), 16-22.

Oyeyinka, S. A., Adeloye, A.A.., Smith, S.A., Adesina, B.O., and Akinwande, F. F. (2019). Physicochemical Properties of Flour and Starch from Two Cassava Varieties. Agrosearch, 19(1): 28-45.

Pearson, D. (1976). The Chemical analysis of foods. (7th ed.). Churchill, Livingstone.

Ramashia, S.E., Anyasi, T.A., Gwata, E.T., Taylor, S.M., Jideani, A.I.O. (2019). Processing, nutritional composition and health benefits of finger millet in sub-saharan Africa. Food Science and Technology, 39 (2), 253-266.

Singh, P. and Raghuvanshi, S. (2012). Finger millet for food and nutritional security. African Journal of Food Science, 6(4), 77-84.

Ukpabi, U.J and Ndimele, C. (1990). Evaluation of garri production in Imo State Nigeria. Nigerian Food Journal, 8, 105-110. 